\title{
Extent of Implementation, Monitoring and Evaluation of School Learning Action Cell (SLAC) as a Cost-effective Learning and Development Strategy for Teachers Development
}

\author{
Carlos Tian Chow C. Correos, Ariel A. Paler* \\ a carl_corr@yahoo.com \\ Division of Surigao del Sur, Tandag City 8300, Philippines
}

\begin{abstract}
The successful implementation of School Learning Action Cell (SLAC) LACs as seen to be the most cost-effective continuing professional development process that improve the teaching-learning process is dependent on how school leaders and teachers understand the process. The consistency of its implementation and monitoring is somehow difficult to achieve when school heads and teachers have limited grasp of the processes and framework of SLACs.

To answer the problems, three sets of survey questionnaires were distributed to 249 school heads and 3,907 teachers in the 37 districts Surigao del Sur Division. Data gathered were analyzed using descriptive statistics.

The results revealed that the school heads understanding and Teachers on SLAC as a strategy for improving instructional delivery was good while teachers understanding was fair. The findings provided evidence that there was only a limited understanding of teachers in the implementation of school learning action cell. Feedback gathered from questionnaires show that teachers did not see how school heads focused the implementation and monitoring of SLAC in schools.

Based on these findings, it is recommended that school heads and teachers must be provided with intensive capacity building on conducting and monitoring of school learning action cell to equip them with knowledge and skills of implementing LAC as a strategy of improving the teaching and learning delivery. It is also recommended to strengthen program implementation review to improve the process of conducting LACs in schools and learning centers.
\end{abstract}

Keywords: School Learning Action Cell; Learning and Development Strategy

\section{Introduction}

The quality of learning is greatly influenced by the quality of teaching. Thus, organizing professional learning communities will aid teachers in the construction of new knowledge about instructional delivery as 
well as revising traditional teaching beliefs and assumptions about education, community and teaching and learning to suit the present needs of learners (DuFour, 2004).

In line with teachers' continuous professional development, the Republic Act No. 10533, or The Enhanced Basic Education Act of 2013, the Department of Education (DepEd) issues the DepEd Order 35, s. 2016, enclosed the policy on the Learning Action Cell (LAC) as the Kto12 Basic Education Program SchoolBased Continuing Professional Development Strategy for the Improvement of Teaching and Learning. This policy aims to engage teachers in a positive, caring, and safe collaborative learning sessions to solve shared challenges encountered in the school facilitated by the school head or a designated LAC Leader.

Supporting this policy are learnings from several interventions in education such as the Program for Decentralized Education (PRODED), Third Elementary Education Project (TEEP), Secondary Education Development and Improvement Project (SEDIP) as well as empirical studies on similar professional development programs that demonstrate teachers' participation in professional development activities have a positive impact on teachers' beliefs and practices, students' learning, and the implementation of educational reforms (UNESCO ISO, 2006).

LACs are seen to be the most cost-effective continuing professional development process that improve the teaching-learning process that will lead to improved learning among the students, nurture successful teachers, enable teachers to support each other to continuously improve their content and pedagogical knowledge, practice, skills, and attitudes; and foster a professional collaborative spirit among school heads, teachers, and the community as a whole (Oakley, et.al., 2018).

Different methods of teacher professional development are implemented throughout the DepEd to improve teaching-learning processes. However, most of these are top-down processes wherein expert knowledge is shared or transferred through lectures or workshops cascaded or echoed teacher training and short-term courses from national, regional and division offices. Other top-down training programs are done over time such as scholarships, and distance learning programs from different training providers and education partners.

Though existing in some schools and districts in Surigao del Sur Division, there are still fewer instances of bottom-up teacher professional development programs where colleagues study content and pedagogies together, plan lessons collaboratively, and conduct action research as a group.

In the context of Surigao del Sur Division, school-based learning action cells, teaching circles, communities of practice, and lesson study are seldom conducted and monitored. LAC frameworks and enabling mechanisms set by DepEd were also given little attention which eventually affects the school's Key Performance Indicators (KPI).

The findings of this study will provide information to Education Specialists/Curriculum Planners of DepEd-Surigao del Sur Division on the current practices and activities of school-based continuing professional development (CPD) through LAC sessions and how LAC framework and mechanisms are implemented as well.

Principals and District Supervisors will be provided also with the status of LAC sessions implementation and monitoring in their respective area and discover challenges working against the success of LAC sessions program and identify ways to better determine teacher needs and demand for continuing professional development.

Moreover, continuous professional development is very important to improve the performance, particularly the teachers in their respective classroom in order to raise students' achievement. As one of the key result areas in the educational process, the need to institutionalize the school learning action cell in the school to improve the teacher's competence is a must. Thus, this study must take action. 


\section{Research Questions}

This research aimed to assess the extent of implementation and monitoring of school learning action cell (SLAC) as a key for continuous learning and development. Specifically, it sought answers to the following questions

1. What is the level of understanding of school leaders and teachers on SLAC as a strategy of improving instructional delivery?

2. What areas of learning are given priorities during SLAC in terms of:
2.1. Learners diversity and inclusion;
2.2. Content and pedagogy;
2.3. Assessment and reporting;
2.4. $21^{\text {st }}$ century skills and ICT integration;
2.5. Curriculum contextualization;
2.6. DepEd thrusts and policies?

3. What monitoring and evaluation strategies are employed by school heads in the implementation of SLAC?

4. What plan of action may be proposed to institutionalize the conduct of school learning action cells?

\section{Innovation, Intervention and Strategy}

This study determined the extent of implementation, monitoring and evaluation of school learning action cells in schools. The innovation also will take into consideration the improved implementation and monitoring mechanisms that will ensure establishment, maintenance, and sustainability of effective SLACs.

A Menu-based Strategic Packaging Framework will be designed to ensure that SLAC mechanisms will be in place. This is a restaurant-inspired strategy which aims to design a perfect menu for costumers. The menu will become contextualized in the different areas and needs of education to be catered for the customers who are teachers and school heads. The menu options will be tailored fit to the needs of the school context and the processes will ensure that DepEd standards stipulated in DO 35, s. 2016 will not be compromised. The framework is shown below.

Figure 1. Menu-based Strategic Packaging Framework

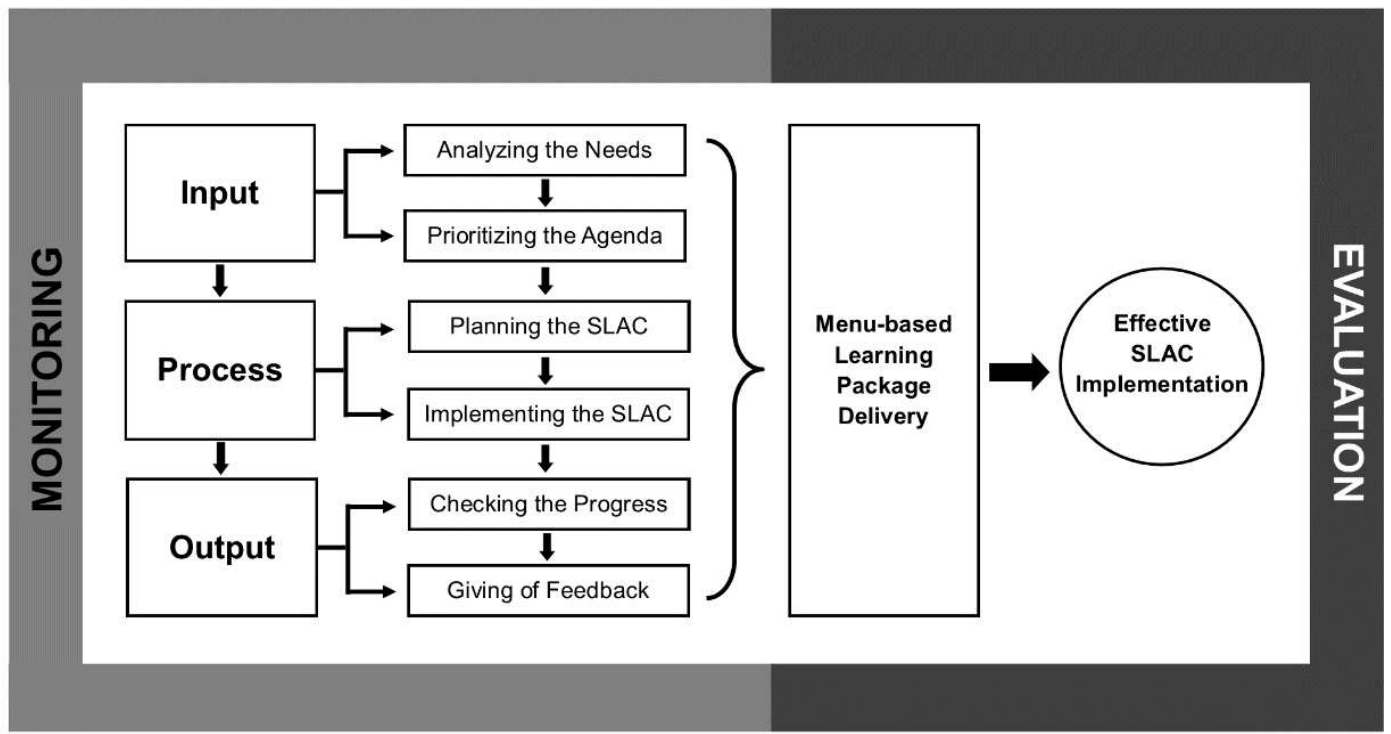




\section{Research Methods}

\subsection{Participants and/or other Sources of Data \& Information}

The respondents in this study were the ten Education Program Supervisors and thirty-five Public Schools District Supervisors/Districts In-charge who are SLAC monitors, three hundred school heads of complete elementary and secondary schools across districts who are SLAC leaders, two hundred master teachers who are SLAC facilitators and four thousand teachers who are SLAC members.

\subsection{Data Gathering Methods}

This study will used mix method. Quantitative and qualitative data gathering was employed to ensure balance between numbers and respondents' qualitative responses. The descriptive method was used through the questionnaires as the main tool complemented with open-ended questions to substantiate the analysis of data gathered from the questionnaire.

This research method obtained firsthand data from the results of the assessment of the respondents which led to the formulation of rational and sound conclusions and recommendations of the study.

Survey and open-ended questionnaires were designed through online methods to prevent face-to-face contact with the respondents. This also provided cost-effective strategy in gathering data since paperless format was used. Health protocols were also considered to make sure that safe operations while conducting the research amidst COVID-19.

\section{Discussion of Results and Reflection}

This portion discuss the extent of implementation and monitoring of school learning action cell (SLAC) as a key for continuous learning and development.

\section{Level of Understanding of School Leaders and Teachers on SLAC as a Strategy for Improving Instructional Delivery}

The table shows that school heads' level of understanding on LAC as a strategy of improving instructional delivery is good. It shows that their understanding on the policies stipulated in DepEd Order No. 35 s. 2020 has the highest mean score of 4.14 followed by their understanding on DepEd Order No. 35 , s. 2016 which is 4.11 and understanding in identifying specific LAC composition with terms of reference and LAC implementation norms that facilitates critical issues which is 4.00. On the other hand, School Heads' capacity to explain theoretical framework, enabling mechanisms and implementation process of LAC in different levels has the lowest mean score of 3. 83. Other indicators with low mean score are School Heads' ability for full grasp of progress monitoring and evaluation mechanisms for LAC's with a mean score of 3.85, specific knowledge on the different topics or areas of discussion for LAC with a mean score of 3.88, and the know how on key aspects within a shared domain of professional interest, self-directed learning and reflective practice leading to action and self-evaluation with a mean score of 3.94. 
Table 1. On School Heads' Level of Understanding on LAC as a Strategy of Improving Instructional Delivery

\begin{tabular}{lcc}
\multicolumn{1}{c}{ Indicators } & Mean & $\begin{array}{c}\text { Level of } \\
\text { Understanding }\end{array}$ \\
\hline $\begin{array}{l}\text { I understand the policies stipulated in DepEd Order No. 35, s. 2020 } \\
\text { including its approaches to professional development programs. }\end{array}$ & 4.14 & Good \\
$\begin{array}{l}\text { I have a full grasp of DepEd Order No. 35, s. 2016 - the Learning Action } \\
\text { Cell as School-based Continuing Professional Development for }\end{array}$ & 4.11 & Good \\
$\begin{array}{l}\text { Improvement of Teaching and Learning. } \\
\text { I can identify specific LAC composition with their terms of reference } \\
\text { and understand the LAC implementation norms that facilitates critical } \\
\text { issues }\end{array}$ & 4.00 & Good \\
$\begin{array}{l}\text { I have the know-how of its key aspects within a shared domain of } \\
\text { professional interest, self-directed learning and reflective practice }\end{array}$ & 3.94 & Good \\
leading to action and self-evaluation & & \\
$\begin{array}{l}\text { I have the specific knowledge on the different topics or areas of } \\
\text { discussion for LAC }\end{array}$ & 3.88 & Good \\
$\begin{array}{l}\text { I have the full grasp of Progress Monitoring and Evaluation mechanism } \\
\text { for LACs }\end{array}$ & 3.85 & Good \\
$\begin{array}{l}\text { I can explain the theoretical framework, enabling mechanisms and } \\
\text { implementation process of LAC in different levels }\end{array}$ & 3.83 & Good \\
\hline
\end{tabular}

Table 2. On Teachers' Level of Understanding on LAC as a Strategy of Improving Instructional Delivery

\begin{tabular}{lcc}
\hline Indicators & Mean & $\begin{array}{c}\text { Level of } \\
\text { Understanding }\end{array}$ \\
\hline $\begin{array}{l}\text { I have a full grasp of DepEd Order No. 35, s. 2016 - the Learning Action } \\
\text { Cell as School-based Continuing Professional Development for }\end{array}$ & 3.35 & Fair \\
$\begin{array}{l}\text { Improvement of Teaching and Learning. } \\
\text { I understand the policies stipulated in DepEd Order No. 35, s. 2020 } \\
\text { including its approaches to professional development programs. }\end{array}$ & 3.34 & Fair \\
$\begin{array}{l}\text { I have the know-how of its key aspects within a shared domain of } \\
\text { professional interest, self-directed learning and reflective practice } \\
\text { leading to action and self-evaluation }\end{array}$ & 3.23 & Fair \\
$\begin{array}{l}\text { I have the specific knowledge on the different topics or areas of } \\
\text { discussion for LAC }\end{array}$ & 3.07 & Fair \\
$\begin{array}{l}\text { I have the full grasp of Progress Monitoring and Evaluation mechanism } \\
\text { for LACs }\end{array}$ & 3.04 & Fair \\
$\begin{array}{l}\text { I can identify specific LAC composition with their terms of reference } \\
\text { and understand the LAC implementation norms that facilitates critical } \\
\text { issues }\end{array}$ & 3.01 & Fair \\
$\begin{array}{l}\text { I can explain the theoretical framework, enabling mechanisms and } \\
\text { implementation process of LAC in different levels }\end{array}$ & 2.96 & Fair \\
\hline
\end{tabular}


Table 2 shows teachers' level of understanding on LAC as a strategy of improving instructional Delivery is fair. Teachers' understanding on DepEd Order No. 35, s. 2016 has the highest mean score of 3.35 followed by teachers' understanding on DepEd Order No. 35 s. 2020 which is 3.34 and teachers' know-how of its key aspects within a shared domain of professional interest, self-directed learning and reflective practice leading to action and self-evaluation which is 3.23. Teachers' capacity to explain theoretical framework, enabling mechanisms and implementation process of LAC in different levels has the lowest mean score of 2.96. Other indicators with low mean scores are teachers' understanding in identifying specific LAC composition with terms of reference and LAC implementation norms that facilitates critical issues which is 3.0 and teachers' ability for full grasp of progress monitoring and evaluation mechanisms for LAC's with a mean score of 3.04, teachers' specific knowledge on the different topics or areas of discussion for LAC with a mean score of 3.07 .

In general, school heads' level of understanding on LAC as strategy of instructional delivery is wider in contrast to teachers' level of understanding. This manifest that leaders in schools are more informed of what Learning Action Cell can do to improve instructions in their respective schools because also of its role as LAC leader. LAC leader will oversee the general activities and will see to it that gaps can be addressed using different learning activities.

It must be noted also that teachers must understand the value of LAC to ensure learning in a continuous process. The connection of school heads' and teachers' understanding of the SLAC must go together to ensure improvement in the delivery of the teaching and learning process. Moreover, they will go hand in hand to improve instruction and increase learning outcomes.

\section{Areas of Learning Priorities by Schools during SLAC}

Table 3. On School Heads' Response about Learners Diversity and Inclusion

\begin{tabular}{lcc}
\hline \multicolumn{1}{c}{ Areas of Learning } & Mean & $\begin{array}{c}\text { Level of } \\
\text { Prioritization }\end{array}$ \\
\hline Differentiated Instruction & 4.62 & Always \\
Inclusive Teaching Strategies & 4.42 & Always \\
Management of Learner Behavior & 4.38 & Always \\
Management of Classroom Structure and Activities & 4.32 & Always \\
Fair Learning Environment & 4.22 & Always \\
Learner Safety and Security & 4.10 & Often \\
Gender Issues and GAD Inclusion & 3.92 & Often \\
Teaching Strategies for Learners under Difficult Circumstances & 3.58 & Often \\
Promotion of Purposive Learning & 3.50 & Often \\
Racial, Ethnic, Linguistic, Religious and Cultural Diversity & 3.10 & Sometimes \\
Teaching Students with Special Needs & 3.05 & Sometimes \\
\hline
\end{tabular}

In response about learner's diversity and inclusion, school heads always prioritize five areas of learning, the following are: differentiated instruction (4.62), inclusive teaching strategies (4.42), management of learner behavior (4.38), management of classroom structure and activities $(4,32)$, and fair learning environment (4.22). School Heads' often prioritize four areas of learning, the following are: learner safety and security (4.10), gender issues and GAD inclusion (3.92), teaching strategies for learner under difficult circumstances (3.58) and promotion of purposive learning (3.50). Two areas of learning revealed as sometimes only taken as priorities by the school head, the following are: racial, ethnic, linguistic, religious and cultural diversity (3.10) and teaching students with special needs (3.05). 
Table 4. On Teachers’ Response about Learners Diversity and Inclusion

\begin{tabular}{lcc}
\hline \multicolumn{1}{c}{ Areas of Learning } & Mean & $\begin{array}{c}\text { Level of } \\
\text { Prioritization }\end{array}$ \\
\hline Management of Classroom Structure and Activities & 4.18 & Often \\
Differentiated Instruction & 4.11 & Often \\
Inclusive Teaching Strategies & 4.00 & Often \\
Gender Issues and GAD Inclusion & 3.97 & Often \\
Fair Learning Environment & 3.80 & Often \\
Management of Learner Behavior & 3.80 & Often \\
Learner Safety and Security & 3.76 & Often \\
Teaching Strategies for Learners under Difficult Circumstances & 2.97 & Sometimes \\
Promotion of Purposive Learning & 2.97 & Sometimes \\
Racial, Ethnic, Linguistic, Religious and Cultural Diversity & 2.92 & Sometimes \\
Teaching Students with Special Needs & 2.51 & Sometimes \\
\hline
\end{tabular}

In the matter on response about learners diversity and inclusion, teachers often prioritize the following areas of learning: management of classroom structure and activities (4.18), differentiated instruction (4.11), inclusive teaching strategies (4.00), gender issues and GAD inclusion (3.97), fair learning environment (3.80), management of learner behavior (3.80), and learner safety and security (3.76). Four areas of learning sometimes taken as priorities by teacher, the following are Teaching Strategies for Learners under Difficult Circumstances (2.97), Promotion of Purposive Learning (2.97), Racial, Ethnic, Linguistic, Religious and Cultural Diversity (2.92), Teaching Students with Special Needs (2.51).

In response about learner's diversity, school heads always prioritize Differentiated Instruction, Inclusive Teaching Strategies, Management of Learner Behavior, Management of Classroom Structure and Activities, and Fair Learning Environment while teachers looked at these as often only. Other indicators where school heads and teachers viewed the same as often are Learner Safety and Security, Gender Issues and GAD Inclusion and Teaching Strategies for Learners under Difficult Circumstances. Moreover, they also view the same as sometimes priority the Racial, Ethnic, Linguistic, Religious and Cultural Diversity and Teaching Students with Special Needs indicators.

Table 5. On School Heads' Response about Content Within and Across Curriculum Teaching Areas

\begin{tabular}{|c|c|c|}
\hline Areas of Learning & Mean & $\begin{array}{c}\text { Level of } \\
\text { Prioritization }\end{array}$ \\
\hline English & 4.30 & Always \\
\hline Mathematics & 4.10 & Often \\
\hline Science & 3.80 & Often \\
\hline Filipino & 3.50 & Often \\
\hline Araling Panlipunan & 3.46 & Often \\
\hline EsP & 3.44 & Often \\
\hline MAPEH & 3.42 & Often \\
\hline TLE & 3.20 & Sometimes \\
\hline
\end{tabular}

In prioritization about content within and across curriculum teaching areas, school heads' always prioritize English (4.30), while Mathematics (4.10), Science (3.80), Filipino (3.50), Araling Panlipunan (3.46), and EsP (3.44), MAPEH (3.42) are often prioritize. The teaching area that sometimes prioritize is only 
TLE.

Table 6. On Teachers' Response about Content Within and Across Curriculum Teaching Areas

\begin{tabular}{|c|c|c|}
\hline Areas of Learning & Mean & $\begin{array}{c}\text { Level of } \\
\text { Prioritization }\end{array}$ \\
\hline English & 3.82 & Often \\
\hline Mathematics & 3.01 & Sometimes \\
\hline Filipino & 2.99 & Sometimes \\
\hline EsP & 2.98 & Sometimes \\
\hline Araling Panlipunan & 2.94 & Sometimes \\
\hline Science & 2.93 & Sometimes \\
\hline MAPEH & 2.92 & Sometimes \\
\hline TLE & 2.51 & Rarely \\
\hline
\end{tabular}

On teachers' response about content within and across curriculum teaching areas, English is often taken into consideration (3.82). Subjects that sometimes prioritize by teachers are, Mathematics (3.01), Filipino (2.99), EsP (2.98), Araling Panlipunan (2.94), Science(2.93), and MAPEH (2.92). The subject that rarely prioritize by teachers are TLE.

School heads view that English is always a priority about content and curriculum while teachers view it as often priority. Subjects like Mathematics, Science, Filipino, Araling Panlipunan, EsP, and MAPEH are viewed by school heads as often a priority while teachers look at it only sometimes. In other hand, TLE is the least subject given the priority both by school head and teachers. School heads view TLE as sometimes while teachers see it as a rarely priority.

Table 7. On School Heads' Response about Pedagogies

\begin{tabular}{lcc}
\hline \multicolumn{1}{c}{ Areas of Learning } & Mean & $\begin{array}{c}\text { Level of } \\
\text { Prioritization }\end{array}$ \\
\hline Strategies for Promoting Literacy and Numeracy & 4.44 & Always \\
Classroom Communication Strategies & 4.12 & Often \\
Strategies for Critical and Creative Thinking & 4.10 & Often \\
Proficient Use of Language in Instruction & 4.00 & Often \\
\hline
\end{tabular}

On school heads' response about pedagogies, they always prioritize Strategies for Promoting Literacy and Numeracy (4.44) while they often prioritize Classroom Communication Strategies (4.12), Strategies for Critical and Creative Thinking (4.10), Proficient Use of Language in Instruction (4.00).

Table 8. On Teachers' Response about Pedagogies

\begin{tabular}{lcc}
\hline \multicolumn{1}{c}{ Areas of Learning } & Mean & $\begin{array}{c}\text { Level of } \\
\text { Prioritization }\end{array}$ \\
\hline Strategies for Promoting Literacy and Numeracy & 3.90 & Often \\
Strategies for Critical and Creative Thinking & 3.80 & Often \\
Classroom Communication Strategies & 3.72 & Often \\
Proficient Use of Language in Instruction & 3.52 & Often \\
\hline
\end{tabular}

On teachers' response about pedagogies, they often prioritize all the areas of learning. Strategies for 
Promoting Literacy and Numeracy has a mean score of 3.90, Strategies for Critical and Creative Thinking has a mean score of 3.80, Strategies for Critical and Creative Thinking has a mean score of 3.72, and Proficient Use of Language in Instruction 3.52.

In comparison, school heads' view Strategies for Promoting Literacy and Numeracy as always, a priority while teachers note it as often a priority. The rest of the indicators they shared the same priority as often in Classroom Communication Strategies, Strategies for Critical and Creative Thinking, and Proficient Use of Language in Instruction.

Table 9. On School Heads’ Response about Assessment and Reporting

\begin{tabular}{lcc}
\multicolumn{1}{c}{ Areas of Learning } & Mean & $\begin{array}{c}\text { Level of } \\
\text { Prioritization }\end{array}$ \\
\hline Designing Formative and Summative Assessment & 4.30 & Always \\
Utilization of Feedback to Improve Learning & 4.30 & Always \\
Selection and Organization of Assessment Methods & 4.28 & Always \\
Utilization of Assessment Strategies & 4.26 & Always \\
\hline
\end{tabular}

On school heads' response about assessment and reporting, all areas of learning are always taken as priority. Designing Formative and Summative Assessment has a mean score of 4.30, Utilization of Feedback to Improve Learning has a mean score of 4.30, Selection and Organization of Assessment Methods has a mean score of 4.28, and Utilization of Assessment Strategies has a mean score of 4.26.

Table 10. On Teachers’ Response about Assessment and Reporting

\begin{tabular}{lcc}
\multicolumn{1}{c}{ Areas of Learning } & Mean & $\begin{array}{c}\text { Level of } \\
\text { Prioritization }\end{array}$ \\
\hline Designing Formative and Summative Assessment & 3.98 & Often \\
Utilization of Assessment Strategies & 3.74 & Often \\
Utilization of Feedback to Improve Learning & 3.74 & Often \\
Selection and Organization of Assessment Methods & 3.70 & Often \\
\hline
\end{tabular}

On teachers' response about assessment and reporting, all areas of learning are often taken as priority. Designing Formative and Summative Assessment has a mean score of 3.98, Utilization of Assessment Strategies and Utilization of Feedback to Improve Learning have a mean score of 3.74, and Selection and Organization of Assessment Methods has a mean score of 3.70.

All areas of assessment and learning are always considered by school heads as a priority such as Designing Formative and Summative Assessment, Utilization of Feedback to Improve Learning, Selection and Organization of Assessment Methods, Utilization of Assessment Strategies while it is often considered only by teachers as often a priority.

Table 11. On School Heads’ Response about 21st Century Skills and ICT Integration

\begin{tabular}{lcc}
\hline \multicolumn{1}{c}{ Areas of Learning } & Mean & $\begin{array}{c}\text { Level of } \\
\text { Prioritization }\end{array}$ \\
\hline Teaching and Learning Resources integrating ICT & 4.42 & Always \\
Positive Use of ICT & 4.40 & Always \\
Technology and Media Literacy & 3.44 & Always \\
Collaboration and Communication Strategies & 3.42 & Always \\
\hline
\end{tabular}


On school heads response about $21^{\text {st }}$ century skills and ICT integration, all areas of learning are always taken as a priority. Teaching and Learning Resources integrating ICT has a mean score of 4.42 , Positive Use of ICT has a mean score of 4.40, Technology and Media Literacy has a mean score of 3.44, and Collaboration and Communication Strategies has a mean score of 3.42.

Table 12. On Teachers' Response about 21st Century Skills and ICT Integration

\begin{tabular}{lcc}
\hline \multicolumn{1}{c}{ Areas of Learning } & Mean & $\begin{array}{c}\text { Level of } \\
\text { Prioritization }\end{array}$ \\
\hline Teaching and Learning Resources integrating ICT & 4.40 & Always \\
Positive Use of ICT & 4.30 & Always \\
Collaboration and Communication Strategies & 3.12 & Sometimes \\
Technology and Media Literacy & 3.08 & Sometimes \\
\hline
\end{tabular}

On teachers' response about $21^{\text {st }}$ century skills and ICT integration, two areas of learning are taken as always priority, Teaching and Learning Resources integrating ICT has a mean score of 4.40 and Positive Use of ICT has a mean score of 3.12. On other hand, two areas of learning are perceived as sometimes taken priority, Collaboration and Communication Strategies with a mean score of 3.12, and Technology and Media Literacy with a mean score of 3.08 .

Two areas of learning about $21^{\text {st }}$ century skills and ICT integration that school heads and teachers set as always a priority which is Teaching and Learning Resources integrating ICT and Positive Use of ICT. In the indicator of Technology and Media Literacy and Technology and Media Literacy, school heads set it as always, a priority while teachers view it as sometimes a priority.

Table 13. On School Heads’ Response about Curriculum Contextualization

\begin{tabular}{lcc}
\hline \multicolumn{1}{c}{ Areas of Learning } & Mean & $\begin{array}{c}\text { Level of } \\
\text { Prioritization }\end{array}$ \\
\hline Lesson Planning & 4.60 & Always \\
Localization and Indigenization of Learning Materials & 4.42 & Always \\
Planning and Management of Teaching-Learning Process & 4.33 & Always \\
\hline
\end{tabular}

School heads' response about curriculum contextualization all areas of learning always considered as a priority. Lesson Planning, Localization and Indigenization of Learning Materials, and Planning and Management of Teaching-Learning Process has a mean score of 4.60, 4.42 and 4.33 respectively.

Table 14. On Teachers' Response about Curriculum Contextualization

\begin{tabular}{lcc}
\hline \multicolumn{1}{c}{ Areas of Learning } & Mean & $\begin{array}{c}\text { Level of } \\
\text { Prioritization }\end{array}$ \\
\hline Lesson Planning & 4.11 & Often \\
Localization and Indigenization of Learning Materials & 3.93 & Often \\
Planning and Management of Teaching-Learning Process & 3.82 & Often \\
\hline
\end{tabular}

Teachers response about curriculum contextualization all areas of learning often considered as a priority. Lesson Planning, Localization and Indigenization of Learning Materials, and Planning and Management of Teaching-Learning Process has a mean score of 4.11, 3.93, and 3.82 respectively. 
Curriculum Contextualization is considered as always a priority of the school heads while teachers only considered as often a priority.

Table 15. On School Heads’ Response about DepEd Thrust and Policies

\begin{tabular}{lcc}
\hline \multicolumn{1}{c}{ Areas of Learning } & Mean & $\begin{array}{c}\text { Level of } \\
\text { Prioritization }\end{array}$ \\
\hline Deped Vision, Mission and Core Values & 4.60 & $\begin{array}{c}\text { Always } \\
\text { The K to 12 Curriculum }\end{array}$ \\
Results-based Performance Management System & 4.60 & Always \\
Philippine Professional Standards for Teachers (PPST) & 4.52 & Always \\
DepEd Strategic Goals and Direction & 4.50 & Always \\
Code of Ethics for Professional Teachers & 4.42 & Always \\
\hline
\end{tabular}

On school heads' response about DepEd thrust and policies, all areas of learning are always a priority. Deped Vision, Mission and Core Values and The K to 12 Curriculum has a mean score of 4.60, Results-based Performance Management System has a mean score of 4.52, Philippine Professional Standards for Teachers (PPST)has a mean score of 4.50, DepEd Strategic Goals and Direction has a mean score of 4.42, and Code of Ethics for Professional Teachers has a mean score of 4.30 .

Table 16. On Teachers’ Response about DepEd Thrust and Policies

\begin{tabular}{lcc}
\multicolumn{1}{c}{ Areas of Learning } & Mean & $\begin{array}{c}\text { Level of } \\
\text { Prioritization }\end{array}$ \\
\hline Results-based Performance Management System & 4.10 & Often \\
The K to 12 Curriculum & 4.02 & Often \\
Philippine Professional Standards for Teachers (PPST) & 4.00 & Often \\
Deped Vision, Mission and Core Values & 3.97 & Often \\
Code of Ethics for Professional Teachers & 3.92 & Often \\
DepEd Strategic Goals and Direction & 3.91 & Often \\
\hline
\end{tabular}

On Teachers' response about DepEd thrust and policies, all areas of learning are often prioritized. Results-based Performance Management System has a mean score of 4.10, The K to 12 Curriculum has a mean score of 4.02, Philippine Professional Standards for Teachers (PPST) has a mean score of 4.00, Deped Vision, Mission and Core Values has a mean score of 3.97, Code of Ethics for Professional Teachers has a mean score of 3.92 and DepEd Strategic Goals and Direction has a mean score of 3.91.

In general, all areas of learning in DepEd thrust and policies are always considered a priority of school heads while teachers considered it only often. It can be deduced that school heads know the importance of the different thrust and policies of the department to as greatly contributed by its role as a lead implementer. 
Monitoring and Evaluation Strategies Employed by School Heads in the Implementation of SLAC

Table 17. On School Heads' Response in Monitoring and Evaluation of SLAC Implementation

\begin{tabular}{lcc}
\hline \multicolumn{1}{c}{ Indicators } & Mean & $\begin{array}{c}\text { Level of } \\
\text { Implementation }\end{array}$ \\
\hline $\begin{array}{l}\text { LAC Planning was done to ensure relevance of current and future } \\
\text { context }\end{array}$ & 4.10 & Often \\
$\begin{array}{l}\text { Progress Checking of LAC Plan was done to ensure implementation } \\
\text { plan is progressing and that LAC sessions are of quality }\end{array}$ & 4.01 & Often \\
$\begin{array}{l}\text { LAC Narrative Reports are consolidated and analyzed for provision of } \\
\text { appropriate interventions }\end{array}$ & 3.96 & Often \\
$\begin{array}{l}\text { Results of monitoring and evaluation was used to review the LAC } \\
\text { implementation cycle to be used as basis for improvement }\end{array}$ & 3.91 & Often \\
$\begin{array}{l}\text { LAC Session Evaluation Tool was used and results were assessed to } \\
\text { ensure mastery and delivery of LACs }\end{array}$ & 3.90 & Often \\
$\begin{array}{l}\text { Monitoring and Evaluation in the conduct of LAC was done regularly } \\
\text { Initial gains from LACs are conducted to measure impact of the } \\
\text { activity such as document analysis of teacher portfolio, reflective }\end{array}$ & 3.89 & Often \\
journals or classroom observation forms \\
$\begin{array}{l}\text { Best practices and innovations from LAC were documented and shared } \\
\text { across schools and districts for adoption of other schools }\end{array}$
\end{tabular}

In monitoring and evaluation strategies employed by school heads in the implementation of SLAC, all indicators are often considered as priorities. Indicators with high mean score are; LAC Planning was done to ensure relevance of current and future context(4.10), Progress Checking of LAC Plan was done to ensure implementation plan is progressing and that LAC sessions are of quality (4.01), LAC Narrative Reports are consolidated and analyzed for provision of appropriate interventions (3.96), Results of monitoring and evaluation was used to review the LAC implementation cycle to be used as basis for improvement (3.91), and LAC Session Evaluation Tool was used and results were assessed to ensure mastery and delivery of LACs (3.90).

Indicators with least mean score are; Program Implementation Review (PIR) and Learning Forum was conducted at the end of the school year to share challenges, innovations and outcomes and celebrating success of LAC (3.65), Best practices and innovations from LAC were documented and shared across schools and districts for adoption of other schools (3.66), Initial gains from LACs are conducted to measure impact of the activity such as document analysis of teacher portfolio, reflective journals or classroom observation forms (3.88), and Monitoring and Evaluation in the conduct of LAC was done regularly (3.89). 
Table 18. On Teachers' Response on School Heads' Monitoring and Evaluation of SLAC Implementation

\begin{tabular}{|c|c|c|}
\hline Indicators & Mean & $\begin{array}{c}\text { Level of } \\
\text { Implementation }\end{array}$ \\
\hline $\begin{array}{l}\text { LAC Planning was done to ensure relevance of current and future } \\
\text { context }\end{array}$ & 2.98 & Sometimes \\
\hline $\begin{array}{l}\text { LAC Session Evaluation Tool was used and results were assessed to } \\
\text { ensure mastery and delivery of LACs }\end{array}$ & 2.93 & Sometimes \\
\hline $\begin{array}{l}\text { Results of monitoring and evaluation was used to review the LAC } \\
\text { implementation cycle to be used as basis for improvement }\end{array}$ & 2.92 & Sometimes \\
\hline $\begin{array}{l}\text { Progress Checking of LAC Plan was done to ensure implementation plan } \\
\text { is progressing and that LAC sessions are of quality }\end{array}$ & 2.91 & Sometimes \\
\hline $\begin{array}{l}\text { LAC Narrative Reports are consolidated and analyzed for provision of } \\
\text { appropriate interventions }\end{array}$ & 2.88 & Sometimes \\
\hline Monitoring and Evaluation in the conduct of LAC was done regularly & 2.86 & Sometimes \\
\hline $\begin{array}{l}\text { Initial gains from LACs are conducted to measure impact of the activity } \\
\text { such as document analysis of teacher portfolio, reflective journals or } \\
\text { classroom observation forms }\end{array}$ & 2.86 & Sometimes \\
\hline $\begin{array}{l}\text { Best practices and innovations from LAC were documented and shared } \\
\text { across schools and districts for adoption of other schools }\end{array}$ & 2.82 & Sometimes \\
\hline $\begin{array}{l}\text { Program Implementation Review (PIR) and Learning Forum was } \\
\text { conducted at the end of the school year to share challenges, innovations } \\
\text { and outcomes and celebrating success of LAC }\end{array}$ & 2.75 & Sometimes \\
\hline
\end{tabular}

In monitoring and evaluation strategies employed by teachers in the implementation of SLAC, all indicators are sometimes considered as priorities. Indicators with high mean score are; LAC Planning was done to ensure relevance of current and future context (2.98), LAC Session Evaluation Tool was used and results were assessed to ensure mastery and delivery of LACs (2.93), Results of monitoring and evaluation was used to review the LAC implementation cycle to be used as basis for improvement (2.92), Progress Checking of LAC Plan was done to ensure implementation plan is progressing and that LAC sessions are of quality (2.91), and LAC Narrative Reports are consolidated and analyzed for provision of appropriate interventions (2.88).

Indicators with least mean score are Program Implementation Review (PIR) and Learning Forum was conducted at the end of the school year to share challenges, innovations and outcomes and celebrating success of LAC (2.75), Best practices and innovations from LAC were documented and shared across schools and districts for adoption of other schools (2.82), Initial gains from LACs are conducted to measure impact of the activity such as document analysis of teacher portfolio, reflective journals or classroom observation forms (2.86) and Monitoring and Evaluation in the conduct of LAC was done regularly (2.86).

In a nutshell, monitoring and evaluation of SLAC implementation is considered by school heads as often priority while teachers considered it as sometimes a priority. This indirectly means that teachers did not feel the monitoring and evaluation activities done by the school heads in the cycle of implementation in schools.

Generally, the results yield difference between how school heads and teachers view the implementation and monitoring of school learning action cell. These results need a cautious evaluation as how LACs are really implemented in schools. The different views will allow division leaders and its top management to design and implement new framework and processes that would allow unified understanding to school heads and teachers on the smooth implementation of LACs in schools. 


\section{Actions Plan for Dissemination and Utilization}

Table 19. Action Plan for the Dissemination and Utilization of Result

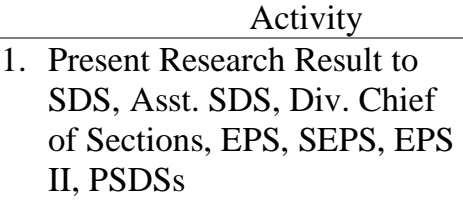

2. Revisit Div. policies that supports the districts and the schools utilizing new framework of implementing LAC

3. Craft Division, District and School Policies to new framework of implementing LAC

4. Create Monitoring and Evaluation team to ensure intensive implementation, monitoring and evaluation of new framework of implementing LAC

5. Monitor and evaluate the implementation of the policies in the division, schools and districts

6. Reporting of feedbacks to evaluate the effectiveness and needs improvement of the policies and implementation for adjustment

\section{To inform top management, EPS, SDS, Asst. SDS, SEPS, EPS II, PSDSs of the result Div. Chief of of the research based from series of Sections, EPS, data gathering and thorough analysis of findings To revisit division districts and school policies that supports utilization of new framework of implementing LAC \\ SEPS, EPS II, \\ PSDSs \\ SDS, Asst. SDS, \\ Div. Chief of \\ Sections, EPS, \\ PSDSs}

To craft Division, District and School Policies to utilize new framework of implementing LAC

To create M \& E Team to monitor and evaluate effectiveness of policies and improvement of the new framework of implementing LAC

To monitor and evaluate the effectiveness of policies and improvement of new framework of implementing LAC

To provide feedbacks of the effectiveness of the policies and needs improvement of the policies and implementation and analysis for adjustments
SDS, Asst. SDS,

Div. Chief of

Sections

August 2020

SDS, Asst. SDS,

Div. Chief of

Sections, EPS,

SEPS, EPS II,

PSDSs

August 2020

Monitoring and

Evaluation Team September to

March 2021

Monitoring and

Evaluation Team September to

March 2021 


\section{References}

DepEd Order 35, s. 2016. Learning Action Cell (LAC) as the Kto12 Basic Education Program School-Based Continuing Professional Development Strategy for the Improvement of Teaching and Learning

DuFour, R. (2004). What Is a “Professional Learning Community?” Educational Leadership, 61(8), 6-11.

Oakley, G., King, R., \& Scarparolo, G. (2018). An evaluation of ELLN Digital: Technology-supported teacher professional development on early language, literacy, and numeracy for K-3 teachers. Quezon City, Philippines: Foundation for Information Technology Education and Development.

Republic Act No. 10533. The Enhanced Basic Education Act of 2013

UNESCO Institute for Statistics (2006). Teachers and Educational Quality: Monitoring Global Needs for 2015. UNESCO Institute for Statistics, Montreal, 2006 
Appendix A. Data Analysis Plan

\begin{tabular}{|c|c|c|c|c|}
\hline Objective/Target & Activity/Task & $\begin{array}{l}\text { Time } \\
\text { Frame }\end{array}$ & Expected Output & $\begin{array}{l}\text { Statistical Tool } \\
\text { to be Used }\end{array}$ \\
\hline $\begin{array}{l}\text { To determine the knowledge } \\
\text { of school leaders on SLAC }\end{array}$ & $\begin{array}{l}\text { Conduct survey to } \\
\text { school leaders }\end{array}$ & $\begin{array}{l}\text { July } 21- \\
24,2020\end{array}$ & $\begin{array}{l}\text { Results of survey } \\
\text { on the knowledge } \\
\text { of school leaders } \\
\text { on SLAC }\end{array}$ & $\begin{array}{c}\text { Survey } \\
\text { questionnaires }\end{array}$ \\
\hline $\begin{array}{l}\text { To describe the steps } \\
\text { employed by school leaders } \\
\text { in deciding the conduct of } \\
\text { SLAC }\end{array}$ & $\begin{array}{l}\text { Float questionnaires } \\
\text { to school leaders by } \\
\text { district }\end{array}$ & $\begin{array}{l}\text { July } 21- \\
24,2020\end{array}$ & $\begin{array}{l}\text { Results of survey } \\
\text { on the steps } \\
\text { employed by } \\
\text { school leaders in } \\
\text { deciding the } \\
\text { conduct of SLAC }\end{array}$ & $\begin{array}{c}\text { Survey } \\
\text { questionnaires } \\
\\
\text { Open ended } \\
\text { questionnaires }\end{array}$ \\
\hline $\begin{array}{l}\text { To identify areas of learning } \\
\text { prioritized during SLAC }\end{array}$ & $\begin{array}{l}\text { Conduct survey to } \\
\text { school leaders, } \\
\text { master teachers and } \\
\text { teaches }\end{array}$ & $\begin{array}{l}\text { July } 21- \\
24,2020\end{array}$ & $\begin{array}{l}\text { List of learning } \\
\text { areas prioritized } \\
\text { during SLAC }\end{array}$ & $\begin{array}{c}\text { Survey } \\
\text { questionnaires }\end{array}$ \\
\hline $\begin{array}{l}\text { To determine the challenges } \\
\text { faced by school leaders in } \\
\text { the conduct of SLAC }\end{array}$ & $\begin{array}{l}\text { Conduct survey to } \\
\text { school leaders, } \\
\text { master teachers and } \\
\text { teaches }\end{array}$ & $\begin{array}{l}\text { July } 21- \\
22,2020\end{array}$ & $\begin{array}{l}\text { List of challenges } \\
\text { faced by school } \\
\text { heads in the } \\
\text { conduct of SLAC }\end{array}$ & $\begin{array}{c}\text { Open-ended } \\
\text { questionnaires }\end{array}$ \\
\hline $\begin{array}{l}\text { To determine the support } \\
\text { mechanisms provided by } \\
\text { Education Program } \\
\text { Supervisors and District } \\
\text { Supervisors in establishing, } \\
\text { maintaining, and sustaining } \\
\text { SLAC practice }\end{array}$ & $\begin{array}{l}\text { Conduct survey to } \\
\text { school leaders, } \\
\text { master teachers and } \\
\text { teaches, EPSs and } \\
\text { PSDSs, DICs }\end{array}$ & $\begin{array}{l}\text { July } 21- \\
24,2020\end{array}$ & $\begin{array}{l}\text { Description of } \\
\text { mechanisms } \\
\text { provided by } \\
\text { Education } \\
\text { Program } \\
\text { Supervisors and } \\
\text { District } \\
\text { Supervisors in } \\
\text { sustaining SLAC } \\
\text { practice }\end{array}$ & $\begin{array}{c}\text { Open-ended } \\
\text { questionnaires }\end{array}$ \\
\hline $\begin{array}{l}\text { To specify the monitoring } \\
\text { and evaluation strategies } \\
\text { employed by Education } \\
\text { Program Supervisors and } \\
\text { District Supervisors in the } \\
\text { implementation of SLAC }\end{array}$ & $\begin{array}{l}\text { Conduct survey to } \\
\text { EPSs and PSDSs, } \\
\text { DICs }\end{array}$ & $\begin{array}{l}\text { July } 27- \\
28,2020\end{array}$ & $\begin{array}{l}\text { List of monitoring } \\
\text { and evaluation } \\
\text { strategies } \\
\text { employed by } \\
\text { Education } \\
\text { Program } \\
\text { Supervisors and } \\
\text { District } \\
\text { Supervisors in the } \\
\text { implementation }\end{array}$ & $\begin{array}{c}\text { Open-ended } \\
\text { questionnaires }\end{array}$ \\
\hline
\end{tabular}

